\title{
Video Article \\ Preparation and Utilization of Freshly Isolated Human Detrusor Smooth Muscle Cells for Characterization of 9-Phenanthrol-Sensitive Cation Currents
}

\author{
John Malysz ${ }^{1}$, Eric S. Rovner ${ }^{2}$, Robert Wake ${ }^{3}$, Georgi V. Petkov ${ }^{1,3,4}$ \\ ${ }^{1}$ Department of Pharmaceutical Sciences, College of Pharmacy, University of Tennessee Health Science Center \\ ${ }^{2}$ Department of Urology, Medical University of South Carolina \\ ${ }^{3}$ Department of Urology, College of Medicine, University of Tennessee Health Science Center \\ ${ }^{4}$ Department of Pharmacology, College of Medicine, University of Tennessee Health Science Center
}

Correspondence to: Georgi V. Petkov at gpetkov@uthsc.edu

URL: https://www.jove.com/video/59884

DOI: doi: $10.3791 / 59884$

Keywords: Immunology and Infection, Issue 155, urinary bladder, smooth muscle, detrusor, cell isolation, enzymatic, human, patch-clamp, amphotericin-B

Date Published: 1/31/2020

Citation: Malysz, J., Rovner, E.S., Wake, R., Petkov, G.V. Preparation and Utilization of Freshly Isolated Human Detrusor Smooth Muscle Cells for Characterization of 9-Phenanthrol-Sensitive Cation Currents. J. Vis. Exp. (155), e59884, doi:10.3791/59884 (2020).

\section{Abstract}

Detrusor smooth muscle (DSM) cells present within the urinary bladder wall ultimately facilitate urine storage and voiding. Preparation of the viable, fresh, and isolated DSM cells presents an important technical challenge whose achievement provides optimal cells for subsequent functional and molecular studies. The method developed and elaborated herein, successfully used by our group for over a decade, describes dissection of human urinary bladder specimens obtained from open bladder surgeries followed by an enzymatic two-step treatment of DSM pieces and mechanical trituration to obtain freshly isolated DSM cells. The initial step involves dissection to separate the DSM layer (also known as muscularis propria) from mucosa (urothelium, lamina propria, and muscularis mucosa) and the adjacent connective, vascular, and adipose tissues present. The DSM is then cut into pieces $\left(2-3 \mathrm{~mm} \times 4-6 \mathrm{~mm}\right.$ ) in nominal $\mathrm{Ca}^{2+}$-containing dissection/digestion solution (DS). DSM pieces are next transferred to and sequentially treated separately with DS containing papain and collagenase at $\sim 37^{\circ} \mathrm{C}$ for $30-45$ min per step. Following washes with DS containing enzyme-free bovine serum and trituration with a fire-polished pipette, the pieces release single DSM cells. Freshly isolated DSM cells are ideally suited for patch-clamp electrophysiological and pharmacological characterizations of ion channels. Specifically, we show that the TRPM4 channel blocker 9-phenanthrol reduces voltage-step evoked cation currents recorded with the amphotericin-B perforated patch-clamp approach. DSM cells can also be studied by other techniques such as single cell RT-PCR, microarray analysis, immunocytochemistry, in situ proximity ligation assay, and $\mathrm{Ca}^{2+}$ imaging. The main advantage of utilizing single DSM cells is that the observations made relate directly to single cell characteristics revealed. Studies of freshly isolated human DSM cells have provided important insights characterizing the properties of various ion channels including cation-permeable in the urinary bladder and will continue as a gold standard in elucidating DSM cellular properties and regulatory mechanisms.

\section{Video Link}

The video component of this article can be found at https://www.jove.com/video/59884/

\section{Introduction}

Detrusor smooth muscle (DSM) cells constitute the most abundant cell type in the urinary bladder and ultimately control urine storage and voiding through relaxation and contraction, respectively. DSM cells form smooth muscle bundles that intertwine with adjacent connective tissue nerve processes, interstitial cells, and other cell types ${ }^{1}$. The current understanding of the role of DSM cells in urinary bladder function has been achieved through a multi-level integrated approach. Each experimental method - whether based on isolated single cells in vitro, tissue strips containing smooth muscle bundles in vitro/ex vivo, or in vivo determinations (such as cytometry and voiding function assessments) - provides important and specific insights into physiological and pharmacological properties of DSM (please see reviews ${ }^{1,2,3,4,5,6}$ for details). However, interpretation of results obtained from isolated single cells allows conclusions to be specifically attributed to the single cell type itself. This realization has been the driving force for establishing a reliable and reproducible method for obtaining freshly isolated DSM cells from the whole thickness urinary bladder specimens. Unlike many other cell types, smooth muscle cells cannot be reliably cultured due to the loss of their native phenotype including specific changes in their electrophysiological and contractile properties ${ }^{7,8}$. This fact further reinforces the importance of studies carried out on physiologically active freshly isolated DSM cells.

In the late 1980's and early 1990's, Isenberg's group (Germany) published a series of electrophysiological studies on freshly isolated DSM cells obtained from guinea pig urinary bladders ${ }^{9,10,11,12,13}$ (Table 1). The method highlighted two important observations that aided in obtaining vital cells and served as an initial guideline for others to follow. They were 1) pre-treating isolated DSM pieces with $\mathrm{Ca}^{2+}{ }_{\text {-free }}$ solution/medium prior to enzymatic treatment and 2) tissue digestion with a solution containing collagenase. These two critical steps have been incorporated into all the subsequent variants of DSM cell dissociation procedures (Table 1). Currently, our group employs a two-step sequential papain-collagenase dissociation approach. DSM pieces are first treated with an enzyme solution containing papain and then with collagenase type II solubilized in 
the same solution (DS, dissection/digestion solution). This approach yields single DSM cells from various species including guinea pig, pig, rat, mouse, and importantly human (Table 1).

Single DSM cells provide a source for multiple molecular biology and physiological experiments. So far, protein and mRNA expressions studied with immunocytochemistry, or RT-PCR/qRT-PCR determinations revealed high levels of detection for various ion channels including the large conductance voltage- and $\mathrm{Ca}^{2+}$-activated (BK), small conductance $\mathrm{Ca}^{2+}$-activated $\mathrm{K}^{+}$type $3(\mathrm{SK} 3)$, voltage-gated $\mathrm{K}^{+}\left(\mathrm{K}_{\mathrm{v}}\right)$, L-type voltage-gated $\mathrm{Ca}^{2+}\left(\mathrm{Ca}_{\mathrm{v}}\right)$, and transient receptor potential melastatin type 4 (TRPM4) channels, as well as a Na/Ca ${ }^{2+}$ exchanger $^{14,15,16,17,18,19,20,21,22}$. They are all thought to control DSM excitability, intracellular $\mathrm{Ca}^{2+}$ levels and contractility. Patch-clamp electrophysiological approaches, performed directly on guinea pig, mouse, rat, or human DSM cells, provided direct demonstration of biophysical and pharmacological properties of $\mathrm{L}_{\text {-type }} \mathrm{Ca}_{\mathrm{v}}$, $\mathrm{K}_{\mathrm{v}}$ $\left(\mathrm{K}_{\mathrm{v}}\right.$ 2.x. $\left.\mathrm{K}_{\mathrm{v}} 7\right)$, SK, BK, and TRPM4 channels ${ }^{17,19,20,21,22,23,24,25,26,27,28,29,30,31}$. The approaches included a conventional whole-cell voltage-clamp, a perforated voltage-clamp, and single-channel recordings (cell attached, inside-out and outside-out configurations). Additionally, membrane potential recording of DSM using a current-clamp provided evidence that target-engaging pharmacological agents alter the cell excitability. For example, the TRPM4 inhibitor 9-phenanthrol induced hyperpolarization in DSM cells obtained from humans, guinea pig, and rat urinary bladders $^{19,20,22,31}$. Among the various electrophysiological methods, the amphotericin-B (and nystatin, gramicidin, and $\beta$-escin) perforated patchclamp recordings provide a key advantage by preserving intrinsic intracellular signaling molecules and pathways. Only low molecular weight cations and to a lesser extent, $\mathrm{Cl}^{-}$- but not proteins or signaling molecules including $\mathrm{Ca}^{2+}$ - are permeable through the plasma membrane pores formed by amphotericin-B or nystati ${ }^{32}$. The successful outcome of perforated patch-clamp experiments depends on several general variables unique to this technique. Here, we describe the details of the procedure utilizing amphotericin-B that our group has used successfully over the years $^{15,22,33,34,35,36,37,38,39}$.

Arguably, non-selective cation channels remain one of the least understood channel types in DSM cells. The first report of a non-selective cation-like channel dates back to 1993 . The paper by Wellner and Isenber ${ }^{11}$ described a $33 \mathrm{pS}$ stretch-activated single channel displaying the following rank order of ion permeability: $\mathrm{K}^{+}>\mathrm{Na}^{+} \geq \mathrm{Cs}^{+}>>>\mathrm{Ba}^{2+}>\mathrm{Ca}^{2+}$, and inhibition of channel activity by $\mathrm{Gd}^{3+}$, a general inhibitor of non-selective cation channels. Almost a decade later, Thorneloe and Nelson ${ }^{40}$ described $\mathrm{Na}^{+}$permeable cation currents in mouse DSM cells, inhibited by $\mathrm{Gd}^{3+}$, using whole-cell recordings. Since molecular identities of non-selective cation channels and their biophysical characterizations remain to be determined, future investigations in this research area are warranted. The protocol described herein for the recording of non-selective cation channel currents - using extracellular and pipette intracellular solutions containing $\mathrm{Cs}^{+}, \mathrm{TEA}^{+}$, and nifedipine (Table 2) that physiologically and pharmacologically mitigate $\mathrm{K}_{\mathrm{v}}$ and $\mathrm{Ca}_{\mathrm{v}}$ currents - has been and will continue to be useful in electrophysiological investigations of non-selective cation channels. We have utilized this specific protocol to determine the extent of inhibition of whole-cell cation currents by the TRPM4 channel blocker 9-phenanthrol in guinea pig, rat and human DSM cells ${ }^{19,20,22}$.

Taken together, the method described here for obtaining freshly isolated single DSM cells from human urinary bladder provides viable cells highly suitable for electrophysiological investigations using various configurations of the patch-clamp technique, $\mathrm{Ca}^{2+}$-imaging, immunocytochemistry, in situ proximal litigation assay, and single cell RT-PCR/qRT-PCR as well as advanced molecular biology techniques including microarray analysis, RNA-seq, and CHIP-seq. The use of the amphotericin-B perforated patch-clamp method preserves the native cell environment unlike other configurations. When carried out using the specific conditions outlined here, designed to negate contributions of $\mathrm{K}^{+}$and $\mathrm{Ca}^{2+} \mathrm{currents}$ in DSM cells, voltage-step induced currents display the properties of non-selective cation currents suitable for biophysical and pharmacological characterizations.

\section{Protocol}

All methods described here have been approved by Institutional Review Board Committees of the University of Tennessee Health Science Center (Memphis, TN, IRB\# 17-05714-XP), and the Medical University of South Carolina (Charleston, SC, IRB\# 00045232). The approved procedures allow whole thickness urinary bladder specimens $(>1 \mathrm{~cm}$ by $>1 \mathrm{~cm})$ - containing all layers including mucosa, detrusor smooth muscle, and serosa as well are attached blood vessels and adipose tissue) - to be collected from patients-donors undergoing surgical partial extraction of bladder. Patient-donors are adult (age range studied until now: 25 to 87 years old), either male or female, with or without symptoms of overactive bladder (as classified by American Urological Association I-PSS score ${ }^{41}$ ). Surgical procedures involve a variety of medical conditions including radical cystectomy for urothelial carcinoma, and adenocarcinoma. In such cases, the collected urinary bladder specimen is remote from the site of tumor.

\section{Dissection of DSM tissues and preparation of mucosa-free DSM pieces}

1. Examine the whole thickness urinary bladder specimen that arrived in the lab from the operating room in a tightly sealed container filled with the cold dissection/digestion solution (Figure 1 and Table 2 for composition of DS).

NOTE: The specimen is usually kept in cold DS from a few hours to overnight prior to arrival in the laboratory. For longer storage, DS (Table 2) is supplemented with $1 \mathrm{mM} \mathrm{CaCl}$.

2. Remove and rinse the human whole thickness DSM specimen (containing all layers including mucosa, DSM, and serosa) with ice-cold DS to wash out attached debris and blood.

3. Pin the urinary bladder specimen, mucosa facing upward and serosa down, onto a silicone enantiomer-coated (Table of Materials) $150 \mathrm{~mm}$ diameter round dish filled with ice-cold DS (Figure 1B).

4. Remove the adjacent adipose tissue, blood vessels, epithelium (urothelium) and muscularis mucosa from the specimen by sharp dissection using microscissors and forceps.

5. Cut out several mucosa-free DSM pieces ( 2-3 mm long and 4-6 mm wide) (Figure 1C).

\section{Enzymatic dissociation of DSM pieces yielding freshly isolated single DSM cells}

1. Place 3 to 6 DSM pieces into a tube containing 1 to $2 \mathrm{~mL}$ of pre-warmed $\left(\sim 37^{\circ} \mathrm{C}\right) \mathrm{DS}$ containing papain and dithiothreitol (DS-P, Table 2$)$ and incubate DSM pieces in DS-P for $30-45 \mathrm{~min}$ at $\sim 37^{\circ} \mathrm{C}$ gently shaking the tube occasionally (once every $10-15 \mathrm{~min}$ ). 
NOTE: To optimally control the temperature for enzymatic treatment, tubes with tissue pieces and enzyme solutions are placed in either a glass tissue chamber filled with water connected to a circulating heated water bath (Figure 1D) or a high-precision temperature-controlled shaking water bath (Figure 1E).

2. Remove DS-P from the tube, briefly wash DSM pieces with ice cold DS, discard cold DS from the tube leaving DSM pieces sitting at the bottom of the tube.

3. Add 1 to $2 \mathrm{~mL}$ of DS-containing collagenase type II (DS-C, Table 2) to the tube with DSM pieces, gently mix; and incubate for 25-40 min at $\sim 37^{\circ} \mathrm{C}$ gently shaking the tube occasionally (every $10-15 \mathrm{~min}$ ).

4. Discard DS-C and wash enzyme-treated DSM pieces 5-10 times with ice-cold DS.

5. Following the last wash, leave DS solution inside the tube; gently triturate with a fire-polished Pasteur pipette several times to release single DSM cells.

6. Place a few drops of DS solution containing dispersed DSM cells onto a glass-bottom chamber or a coverslip and visually inspect for the quality under a microscope (using a $20 x$ or $40 x$ objective) after at least 5 min following the application to allow the cells to adhere to the bottom.

7. Immediately use freshly isolated DSM cells for electrophysiological experiments or store the cells in a tube containing DS at $\sim 4{ }^{\circ} \mathrm{C}$ either on ice or in a refrigerator until use (typically for up to $8 \mathrm{~h}$ of preparation).

NOTE: Within the same preparation the quality of cells varies from highly viable to over-digested, dead DSM cells (Figure 2). When the sequential papain-collagenase method yields a very high number of unviable cells, the preparation is discarded, and a new digestion of DSM pieces is carried out but with reduced incubation intervals. If the procedure results in too few DSM cells then for the subsequent digestion of DSM pieces, the incubation intervals are increased. Positive immunoreactivity to a-smooth muscle actin confirms the identity of DSM cells (Figure 3).

\section{Recording voltage-step induced cation currents from DSM cells using amphotericin-B perforated whole-cell voltage patch-clamp technique}

1. Pipette $0.25-1 \mathrm{~mL}$ of cell suspension onto a glass bottom chamber sitting on a stage of an inverted microscope and allow the cells to adhere to the glass bottom.

2. After incubation for at least $45 \mathrm{~min}$, remove DS from the bath and replace with the $E$ solution (Table 2) by superfusion where the solution flow aided by gravity via inlet tubing slowing replaces DS with the new solution while outlet tubing connected to a vacuum waste vessel removes the chamber solution and prevents overflow. Note that $\mathrm{E}$ solution contains tetraethylammonium $\left(\mathrm{TEA}^{+}\right)$and cesium $\left(\mathrm{Cs}^{+}\right)$ions to inhibit $\mathrm{K}^{+}$ currents.

3. Prepare a working stock solution of amphotericin-B in dimethyl sulfoxide (DMSO) (1 $\mathrm{mg}$ per $10 \mu \mathrm{L}$ of DMSO). To fully dissolve amphotericin powder, sonicate (at least $15 \mathrm{~min}$ ) and vortex the solution well.

NOTE: This step usually takes less than $10 \mathrm{~min}$. Dissolving 3-4 mg of amphotericin-B in $30-40 \mu \mathrm{L}$ of DSMO in a $1.5 \mathrm{~mL}$ microcentrifuge tube works well. Higher quantities of amphotericin-B require more DSMO solvent typically resulting in a longer interval for mixing and incomplete solubilization of the amphotericin-B solid particles present in the tube.

4. Dissolve stock solution of amphotericin-B in the pipette solution (solution $P$, Table 2) to obtain a final concentration of $200-500 \mu \mathrm{g} / \mathrm{mL}$. This step requires extensive sonication and vortexing at a high-speed setting (8-10/10) for $\sim 30$ to 60 min per step to ensure optimal mixing and prevention of amphotericin-B precipitate formation in the pipette solution.

NOTE: Amphotericin-B will precipitate over-time and is light-sensitive. The working pipette solution containing Amphotericin-B is checked for solubility, hand-mixed prior to pipette filling, and kept in the dark.

5. Pull multiple patch electrodes, fire-polish electrode tips, and (if needed) coat the tips with dental wax.

6. Fill the tip of a patch electrode with the pipette solution (solution P, Table 2) without amphotericin-B by briefly dipping the electrode in the solution.

7. Backfill the electrode with the same pipette solution containing amphotericin-B

8. Mount the electrode onto a holder connected to a patch-clamp amplifier headstage.

9. Using a micromanipulator, place the electrode just below the surface of the extracellular solution so that the tip of the electrode is just submerged.

10. In the voltage-clamp mode, set the holding potential to $0 \mathrm{mV}$ and adjust the current to $0 \mathrm{pA}$ with the pipette offset dial on the commercial amplifier (Table of Materials).

11. Determine the electrode resistance using the Membrane Test window/function of the commercial acquisition software (Table of Materials). To activate click Tools>Membrane Test>Play or a shortcut icon in the software. The determined electrode resistance should be in the range of 2 to $5 \mathrm{M} \Omega$.

NOTE: Membrane Test function provided in the commercial acquisition software or Seal Test option on the amplifier can be used to monitor electrode resistance by applying voltage steps repetitively.

12. Continue monitoring electrode resistance while advancing the electrode toward a chosen DSM cell with a micromanipulator (Figure 4A) NOTE: To be considered a viable DSM cell, the cell must show spindle-shaped elongated morphology, a well-defined halo around the cell, crisp edges, and semi-contractile (serpentine) appearance.

13. When touching the cell surface with the electrode - indicated by a rapid increase in the electrode resistance measured with the Membrane Test function - form a giga-seal by applying gentle rapid negative pressure to the electrode holder via tubing. This results in negative pressure created at the tip of the electrode that pulls cell membrane into electrode aiding in the formation of a giga-seal or a very tight contact between the electrode and plasma membrane (Figure 4B).

14. Once the giga-seal forms, compensate pipette capacitance by adjusting fast and slow dials on the commercial amplifier and monitor giga-seal stability (leak current) using the Membrane Test function.

15. Allow time, typically 30-60 min, for amphotericin-B to diffuse down the pipette and be inserted into the plasma membrane forming pores primarily selective to monovalent cations. During this step, continue monitoring the giga-seal with the Membrane Test function. As cell perforation increases so does the amplitude of the capacitance transients (compare Figure 4B versus Figure 4C displaying no and effective cell perforation, respectively) measured with the Membrane Test function. 
16. When the patch perforation is optimal (judged by stable series resistance typically below $50 \mathrm{M} \Omega$ ), cancel out the capacitance transients by adjusting the dials for cell capacitance and series resistance on the amplifier. Series resistance compensation can also be performed at this time (Figure 4D).

17. Once stable voltage-step induced cation currents evoked by the specified protocol are observed, apply a compound or physiological condition to test by superfusion and record the responses for the control-, test-condition, and washout (if possible) with the commercial acquisition software.

1. Record currents with a routine voltage-step protocol that involves holding DSM cells at -64 or $-74 \mathrm{mV}$ and stepping the voltage in 10 $\mathrm{mV}$ increments for 400 or $500 \mathrm{~ms}$ from -94 to +96 or $+106 \mathrm{mV}$ and returning to the holding potential.

NOTE: The membrane potential values are adjusted for a liquid junction potential of $14 \mathrm{mV}$ (using $\mathrm{P}$ and $\mathrm{E}$ solutions, Table 2). The liquid junction potential is obtained in the commercial acquisition software (Table of Materials) by clicking (Tools $>$ Junction Potentials) and entering the concentrations of solution ion components. A ramp protocol can also be used to obtain current recordings.

2. Run the voltage-protocol in continuous $\sim 1 \mathrm{~min}$ interval during an experiment recording currents for pre-addition control, test condition, and washout.

\section{Data analysis and visualization}

1. Open recorded files in the commercial data analysis software (Table of Materials) for the control, test condition, and washout by clicking File>0pen Data and selecting files of interest for opening.

NOTE: For analysis typically three files (each containing a single set of traces to a single protocol run) for each condition are opened and analyzed. The responses are subsequently averaged to obtain a mean response for each condition. The software used for data acquisition contains an option to automatically collect user-specified multiple test runs and average them for single output file that can be used as an alternative.

2. Obtain the average response over the last $200 \mathrm{~ms}$ for the current trace measured at each voltage; the duration interval chosen reflects a steady-state level of voltage-step current activation. To do so follow the steps below.

1. Select a file of interest for analysis in the commercial analysis software (Table of Materials).

NOTE: The software positions the most recently imported file into its active display window. The open file displays a series of overlapping traces obtained with a voltage-step protocol. By default, within the active window four cursors (displaying $\mathrm{x}$ and $\mathrm{y}$ values for the highlighted trace) are shown.

2. Choose the range for analysis by positioning cursor 2 at the end of the 400 or $500 \mathrm{~ms}$ voltage step and cursor 1 at the interval of 200 $\mathrm{ms}$ before that so that the analysis range is $200 \mathrm{~ms}$.

3. Obtain responses for each voltage by clicking Analyze>Quick Graph>IV (or the IV shortcut icon) (in the prompt window before generating data confirm that for $y$-axis (Current) signal Region options "Cursors 1..2" and "Mean" are selected). Click OK to generate the I-V graph and to place the data into a Results column sheet that can be viewed by accessing Windows $>$ Results.

4. Analyze additional files by repeating steps 4.2.1 - 4.2.3. Click Analyze>Quick Graph>IV or the IV icon shortcut, select Append rather than Replace to add additional data to the Results sheet when processing the traces.

5. Copy data to a spreadsheet by selecting the columns of interest and pressing $\mathbf{C T R L + C}$ to copy and $\mathbf{C T R L + V}$ to paste. Store the Results worksheet in the commercial analysis software (Table of Materials) in ( ${ }^{*}$.rlt) format by clicking File>Save As.

3. For each cell, normalize the responses for all three conditions to the value of the maximum voltage step for the pre-addition control

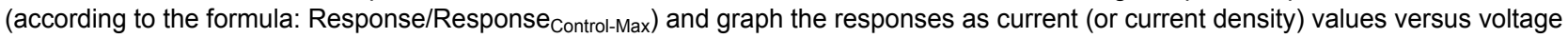
relationships (Figure 6).

1. In a worksheet processor, determine the average responses as either currents $(p A)$ or current densities $(p A / p F)$ for control, test condition (in this example, 9-phenanthrol), and washout at each voltage step.

2. Divide values for each voltage of each condition (control, 9-phenanthrol, and washout) by the maximum control response obtained at the highest voltage $(+96 \mathrm{mV}$ in Figure 6$)$ for the pre-addition control following the formula: Normalized response for condition $(x)=$

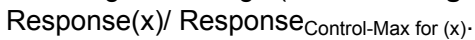

4. For summary analysis, arrange the data in a format that can be easily copied to a graphical program (e.g. GraphPad Prism) for visualization.

\section{Representative Results}

Enzymatic dissociation of DSM pieces provides healthy freshly isolated DSM cells routinely used in functional and molecular studies such as: patch-clamp electrophysiology and immunocytochemistry. Figure 1 summarizes the dissection steps and visualizes the setups employed for temperature control of enzymatic treatment steps. Figure 2 illustrates bright-field images of DSM cells obtained from three human urinary bladder specimens each from a different patient-donor. Healthy single DSM cells are characterized by spindle-shaped morphology, crisp welldefined edges, a well-defined halo around the cell, and semi-contractile (serpentine-like) appearance when viewed under the microscope (see DSM cells demarked by white arrows in Figure 2). They also respond to contraction stimulating agents such as the muscarinic agonist carbachol or high $\mathrm{K}^{+}(60 \mathrm{mM})$ applications. DSM cells show positive immunoreactivity for $\alpha$-smooth muscle actin confirming their identity (Figure 3).

DSM cells are ideally suited for patch-clamp electrophysiological investigations of ion channel properties. Here, we describe the amphotericinB perforated patch-clamp recording method using pipette and extracellular solutions (Table 2) to optimally record voltage-step induced cation channels. Under the specific conditions employed, blockade of $\mathrm{K}_{\mathrm{v}}$ and L-type $\mathrm{Ca}^{2+}$ currents with $\mathrm{Cs}^{+} / \mathrm{TEA}^{+}$and nifedipine, respectively, ensured the elimination of contribution of these ionic components to the whole-cell voltage-evoked currents. Figure $\mathbf{4}$ and Figure $\mathbf{5}$ show, respectively, the experimental steps of the amphotericin-B perforated patch-clamp method and representative whole-cell currents measured either with a voltage-step induced or a ramp protocol in three different human DSM cells, each from a different patient donor. Note that the recordings display a certain degree of variability in terms of current amplitudes and outward rectification. Additional experiments revealed that 9-phenanthrol, a 
TRPM4 channel inhibitor, effectively and reversibly inhibited human DSM cation currents at negative and positive voltages (Figure 6). The 9phenanthrol-sensitive current component illustrates a stronger inhibition at positive voltages and outward rectification (Figure 6C).
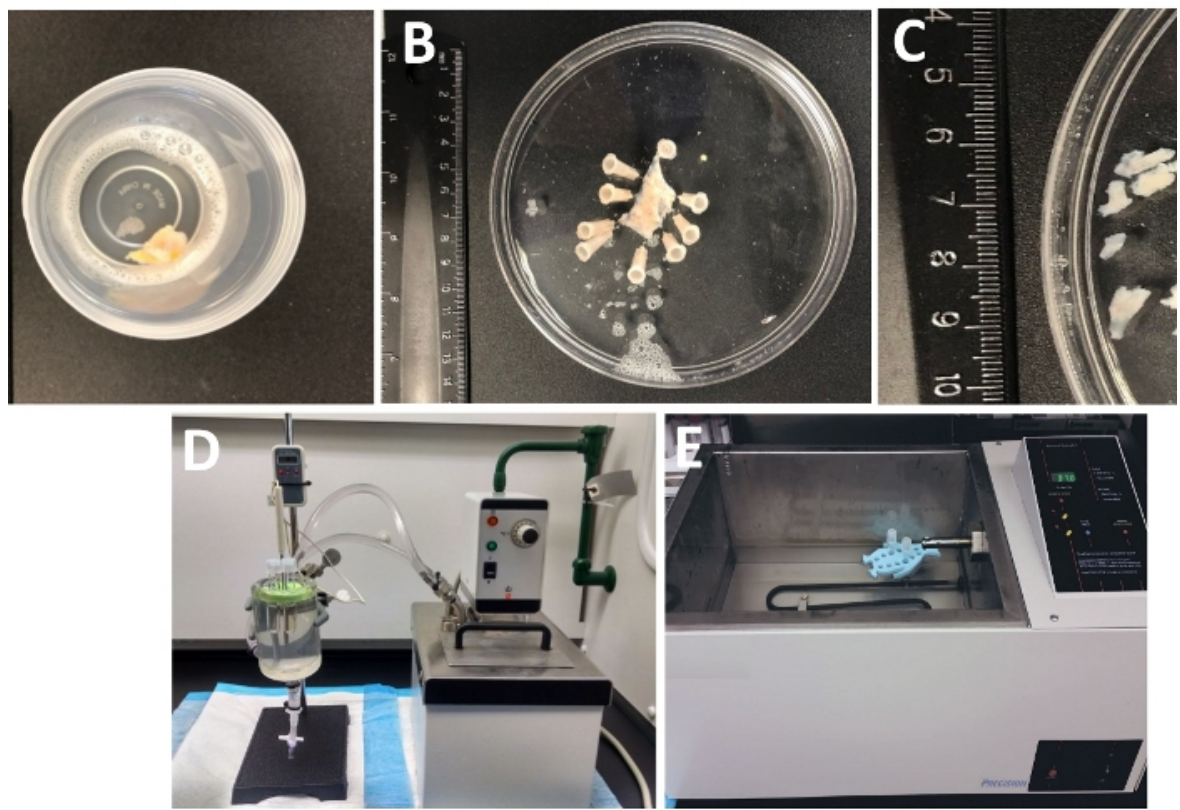

Figure 1: Summary of dissection steps resulting in the preparation of detrusor smooth muscle (DSM) pieces and setup used for enzymatic dissociation. Shown are images of: $(\mathbf{A})$ a whole thickness human urinary bladder specimen provided from an open bladder surgery as extraneous surgical material in ice-cold DS, (B) the same preparation after pinning with a partially dissected DSM layer, (C) DSM pieces of variable dimensions cut out from the DSM layer ready for enzymatic digestion (smaller pieces) or other experimental investigations (larger pieces), (D, E) alternative setups used for enzymatic digestion of DSM pieces consisting of either (1) a temperature-controlled circulating water bath connected via tubing to a large glass tissue chamber filled with water, a rubber holder for tubes, plastic tubes containing DSM pieces and enzyme solutions prepared in dissection/digestion solution (DS, either DS-P or DS-C, Table 2) and a temperature probe linked to a display allowing for continuous monitoring (D), or (2) a large water-filled temperature-controlled bath containing a holder and tubes with DSM pieces and enzyme solutions (E). Please click here to view a larger version of this figure.
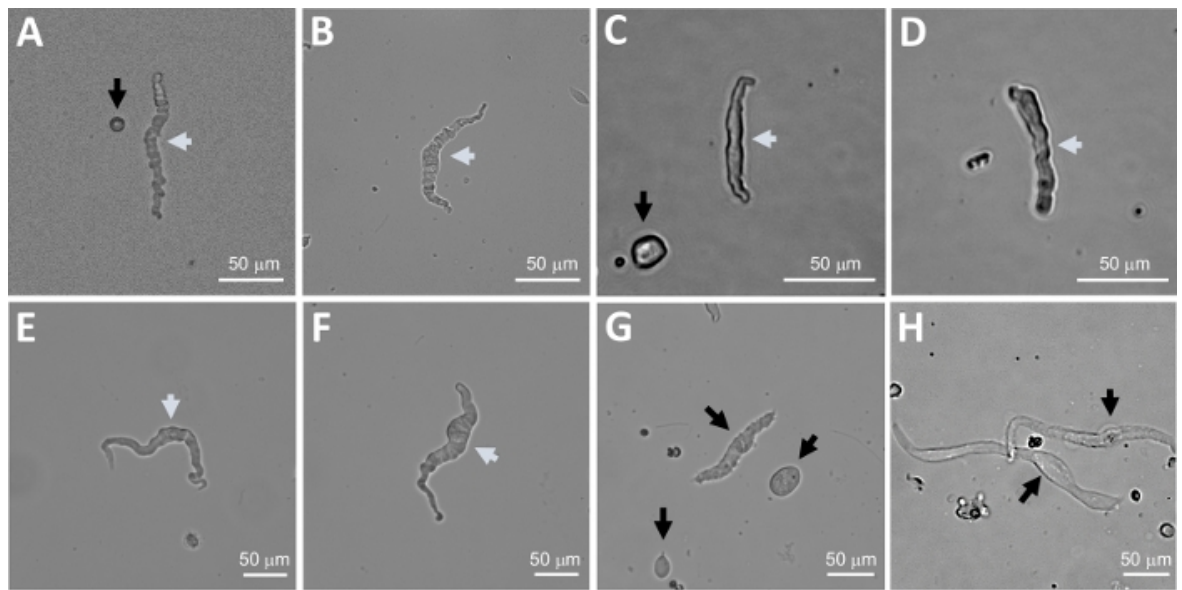

Figure 2: Representative bright-field images of human freshly isolated DSM cells obtained using the sequential papain-collagenase digestion method. (A-F) Displayed are images of viable, physiologically active DSM cells considered suitable candidates for attempting perforated patch-clamp recordings. $(\mathbf{G}, \mathbf{H})$ Images of non-viable or over-digested cells; such cells were avoided for patch-clamp experiments. White and black arrows in panels $(\mathbf{A}-\mathbf{H})$ point to DSM cells considered viable and non-viable, respectively, for attempting patch-clamp recordings. Note that the black arrows in panels $(\mathbf{A}, \mathbf{C}$, and $\mathbf{G}$ ) point to cell fragments (circular pieces) or small cells lacking DSM morphology and in (H) the cells appear pale and dilated. Images are from three different urinary bladder specimens (A and B : patient-donor source one, $\mathbf{C}$ and $\mathbf{D}$ : patientdonor source two, and E-H : patient-donor source three). Please click here to view a larger version of this figure. 
A
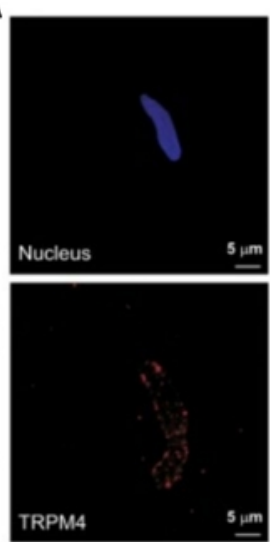
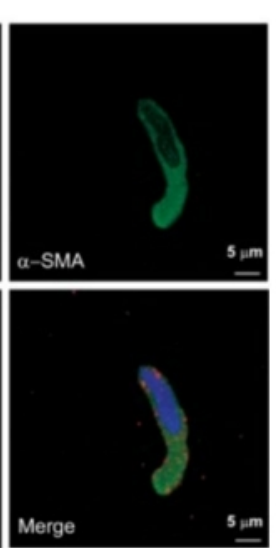

B

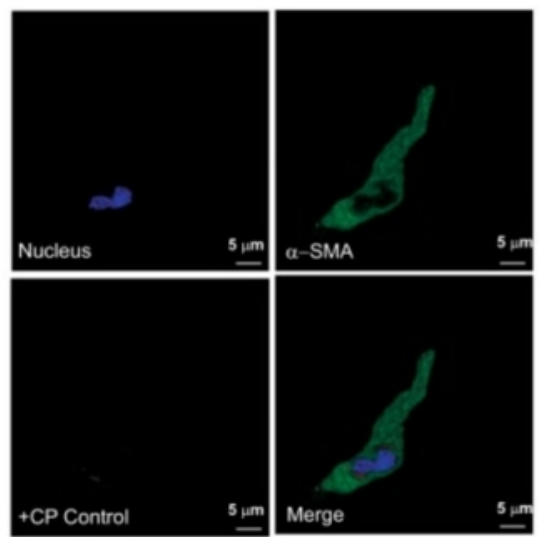

Figure 3: Expressions of transient receptor potential melastatin type 4 (TRPM4) channel and $\alpha$-smooth muscle specific actin immunoreactivities in single human DSM cells by immunocytochemistry analysis. (A) Shown are confocal images showing immunocytochemical detection of TRPM4 channel protein expression in a human DSM cell. Red staining (bottom left) indicates TRPM4 channel proteins; blue (DAPI) staining detects cell nuclei (top left); green staining indicates $\alpha$-smooth muscle actin ( $\alpha$-SMA, top right); the merged image (bottom right) illustrates the overlap of all three images. (B) Confocal images illustrating attenuation of immunocytochemical detection of TRPM4 channel protein expression in the presence of a TRPM4-specific competing peptide (CP) in isolated human DSM cells. Blue (DAPI) staining indicates cell nuclei (top left); green staining is for $\alpha$-smooth muscle actin ( $\alpha$-SMA, top right); the merged image (bottom right) illustrates the overlap of all three images. The results were verified in four separate experiments using DSM whole tissue or multiple DSM cells isolated from four patients. Images are from Hristov et al. $(2016)^{22}$ and used with permission. Please click here to view a larger version of this figure.

A
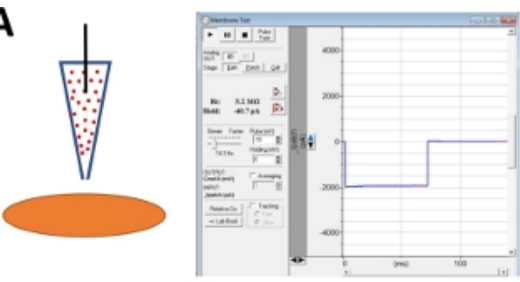

C
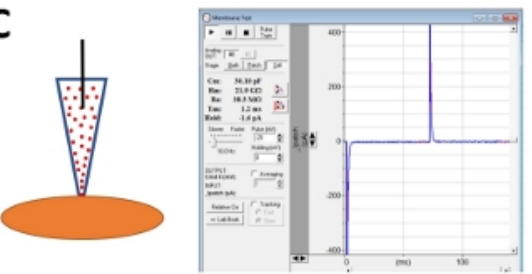

B

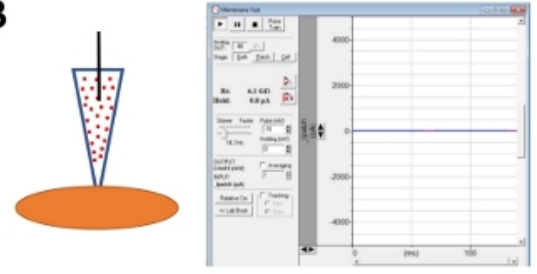

D
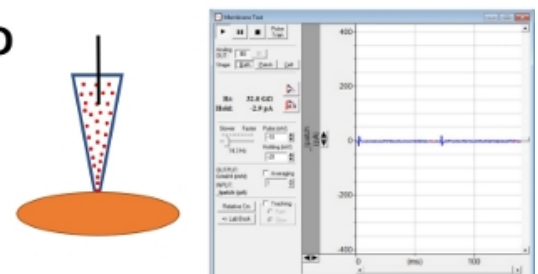

Figure 4: Schematic illustration of steps involved in giga-seal formation and amphotericin-B perforation of human DSM cells. Illustrated are spatial positions of an amphotericin-B containing pipette and a DSM cell along with associated responses for membrane tests obtained in the commercial acquisition software (Table of Materials) by altering voltage steps (either -10 or $-20 \mathrm{mV}$ in this example) determining resistance. Configurations are: (A) prior to the cell approach with an electrode, (B) after giga-seal formation obtained by positioning the amphotericin-B containing pipette (amphotericin-B represented by red dots) onto the cell surface and applying negative pressure, (C) the on-cell configuration shown $\sim 45$ min after giga-seal formation, at this time-point amphotericin-B has diffused down the pipette and its molecules have inserted into the plasma membrane at the tip of the electrode forming cation permeable pores, and (D) the same configuration as in (C) but with capacitance transients canceled out using dials for whole-cell capacitance and series resistance on the amplifier. Please click here to view a larger version of this figure. 
A

$$
-74 \mathrm{mV} \underset{-94 \mathrm{mV}}{+96 \mathrm{mV}}
$$
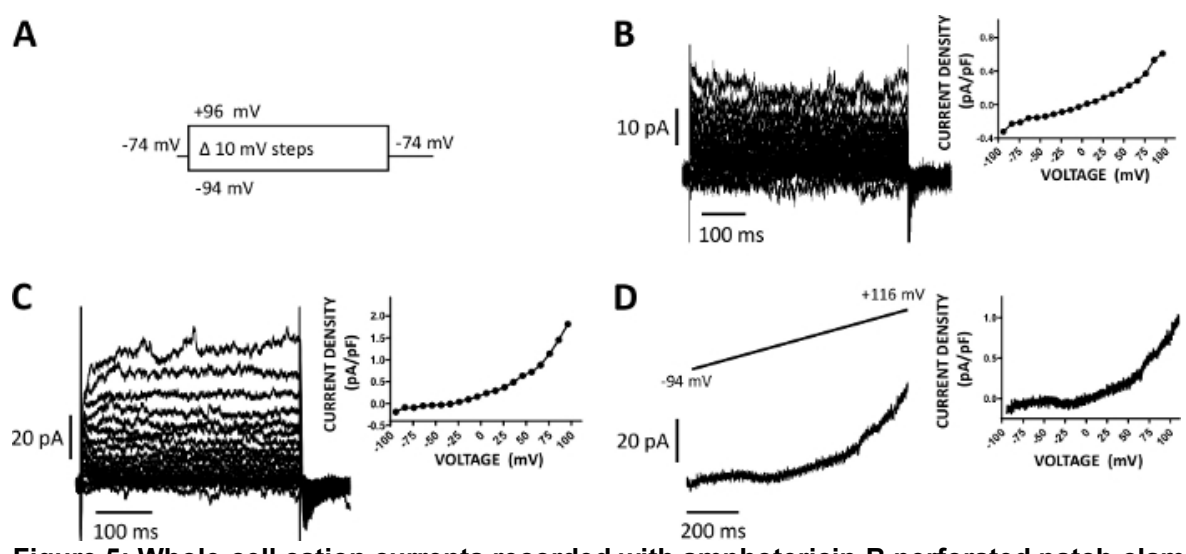

of the voltage-step protocol illustrates a holding potential $\mathrm{mV}$ increments and then returned to $-74 \mathrm{mV}$. (B, C) Representative current traces along with current density-voltage plots from two different human DSM cells, each from a different urinary bladder specimen/patient-donor obtained with the voltage-step protocol described in (A). (D) An example of a current trace obtained with a ramp protocol (graphically represented in the top inset as voltage change from -94 to $+116 \mathrm{mV}$ over a $1 \mathrm{~s}$ duration at $0.21 \mathrm{mV} / \mathrm{ms}$, holding potential was $-94 \mathrm{mV}$ ). On the right in panels (B-D), the graphs display the current density-voltage relationship for each DSM cell recorded. Please click here to view a larger version of this figure.

A

CONTROL

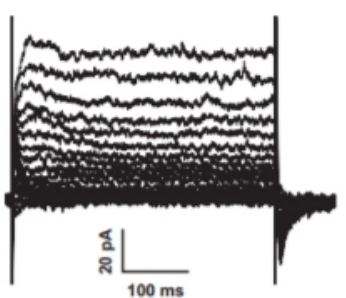
9-PHENANTHROL $(30 \mu \mathrm{M})$
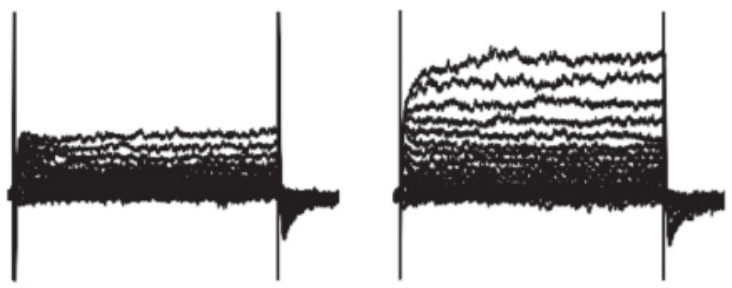

B
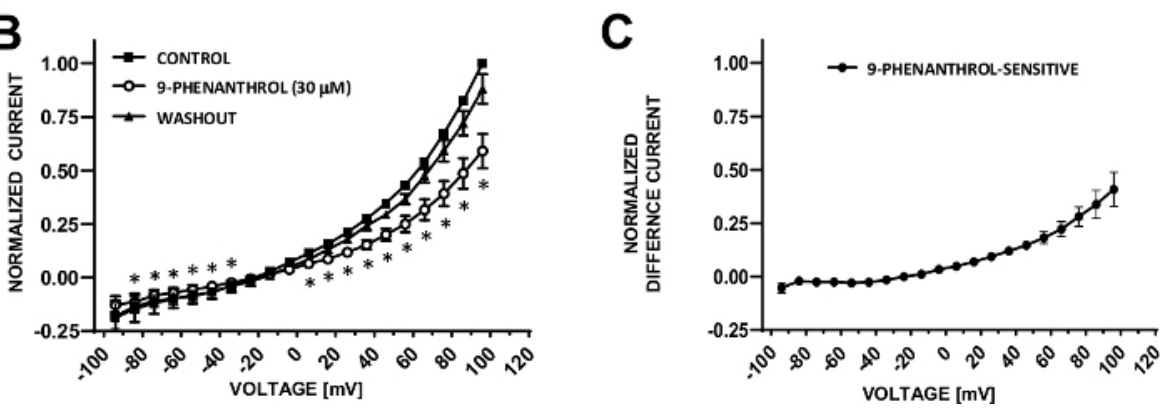

Figure 6: TRPM4 channel blocker 9-phenanthrol-mediated inhibition of voltage-step induced cation currents in human DSM cells. (A) Shown are representative currents measured with the voltage-step protocol described in Fig. 5A for control, 9-phenanthrol, and washout. (B) Summary of normalized responses versus voltage for control, 9-phenanthrol, and washout in seven DSM cells (from seven different patientdonors). (C) Difference current for 9-phenanthrol-sensitive component obtained by subtracting the values in the presence of 9-phenanthrol (30 $\mu \mathrm{M})$ from those of the control shown in (B). Data in (B) and $(\mathbf{C})$ are displayed as means with error bars for SEM, * depicts significance $(p<0.05$, paired Student's test) for the comparison of control vs 9-phenanthrol at each voltage. Panels (A) and (B) have been reproduced from Hristov et al. $(2016)^{22}$ and used with permission. Please click here to view a larger version of this figure. 


\begin{tabular}{|c|c|c|}
\hline Species & Procedure Details & References \\
\hline Guinea pig & 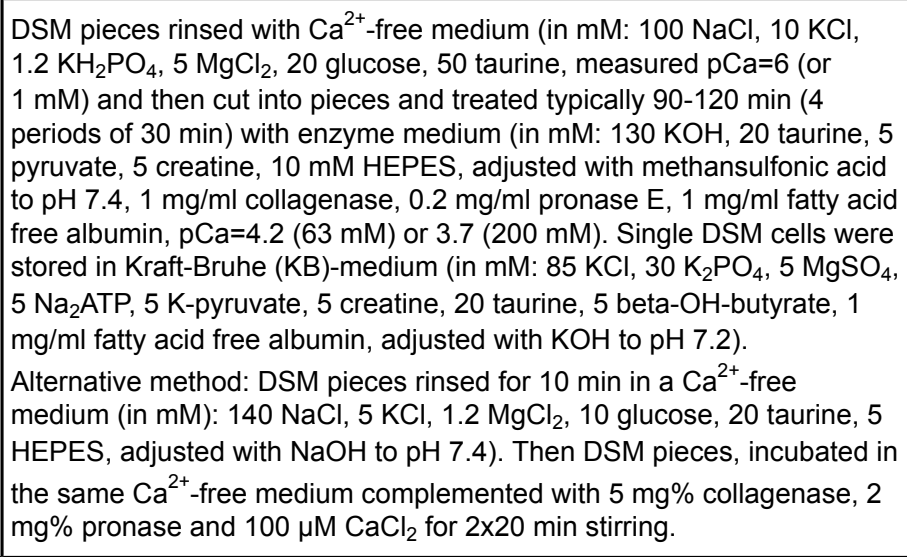 & $\begin{array}{l}\text { Klockner \& Isenberg }(1985)^{13,34} \\
\text { Klockner \& Isenberg (1986) } \\
\text { Schneider et al. }(1991)^{10} \text { Bonev } \\
\text { \& Isenberg }(1992)^{9} \text { Weidelt \& } \\
\text { Isenberg }(2000)^{36} \text { Moore et al. } \\
(2004)^{14}\end{array}$ \\
\hline $\begin{array}{l}\text { Guinea pig, Landrace pig, and } \\
\text { human }\end{array}$ & $\begin{array}{l}\text { DSM pieces pre-incubated for } 5 \text { min in } \mathrm{Ca}^{2+} \text {-free Krebs solution then } \\
\text { cut into pieces and enzymatically digested in } \mathrm{Ca}^{2+} \text {-free Krebs solution } \\
\text { containing } 0.5-2 \mathrm{mg} / \mathrm{ml} \text { collagenase type I and } 0.1-0.5 \mathrm{mg} / \mathrm{ml} \text { pronase } \\
\text { at } 36^{\circ} \mathrm{C} \text { for } 20-30 \mathrm{~min} \text { constantly stirred. In some cases, digested } \\
\text { pieces were further agitated by a blunt tipped pipette or by spinning } \\
\text { until yielding cells. Isolated cells were stored in modified Krebs solution } \\
\text { (described in Klockner \& Isenberg }{ }^{13} \text { ) and were normally used within } 3 \mathrm{~h} \text {. } \\
\text { The composition of the Krebs solution was (mM): } 140 \mathrm{Na}^{+}, 6 \mathrm{~K}^{+}, 2 \mathrm{Ca}^{2+} \text {, } \\
1.2 \mathrm{Mg}^{2+}, 152.4 \mathrm{Cl}^{-}, 10 \text { glucose, } 10 \mathrm{HEPES}, \mathrm{pH} 7.35-7.4 \text { with Tris. For } \\
\mathrm{Ca}^{2+} \text {-free solution, } \mathrm{Ca}^{2+} \text { and } \mathrm{Mg}^{2+} \text { were omitted from the Krebs solution. }\end{array}$ & $\begin{array}{l}\text { Inoue \& Brading }(1990)^{37} \text { Inoue } \\
\text { \& Brading }(1991)^{38} \text { Nakayama \& } \\
\text { Brading }(1995)^{39}, 40\end{array}$ \\
\hline Human & $\begin{array}{l}\text { DSM pieces placed in } \mathrm{Ca}^{2+} \text {-free HEPES Tyrode's solution (in mM: } 105.4 \\
\mathrm{NaCl}, 20.0 \text { or } 22.3 \mathrm{NaHCO}_{3}, 3.6 \mathrm{KCl}, 0.9 \mathrm{MgCl}_{2}, 0.4 \mathrm{NaH}_{2} \mathrm{PO}_{4}, 19.5 \\
\text { or } 4.9 \mathrm{HEPES}, 5.4 \text { or } 5.5 \text { glucose, } 4.5 \text { or } 5.5 \mathrm{Na} \text {-pyruvate) and cut into } \\
\text { DSM pieces. DSM pieces soaked in an enzyme solution }\left(\mathrm{Ca}^{2+} \text { free }\right. \\
\mathrm{HEPES} \text { solution with } 0.7 \mathrm{mg} / \mathrm{ml} \text { collagenase type I, } 0.7 \mathrm{mg} / \mathrm{ml} \text { papain, } 1 \\
\mathrm{mg} / \mathrm{ml} \text { albumin) overnight at } 4^{\circ} \mathrm{C} \text {. The strips were then heated at } 36.5^{\circ} \mathrm{C} \\
\text { for } 15 \text { to } 30 \mathrm{~min} \text {, washed and gently triturated in fresh solution. Isolated } \\
\text { cells that were stored in } \mathrm{Ca}^{2+} \text { containing HEPES Tyrode's solution or } \\
\text { used immediately for experiments. }\end{array}$ & $\begin{array}{l}\text { Montgomery \& Fry }(1992)^{24} \\
\text { Gallegos and Fry }(1994)^{41} \text { Fry et } \\
\text { al. }(1994)^{42} \text { Sui et al. }(2001)^{43} \mathrm{Wu} \\
\text { et al. }(2002)^{44}\end{array}$ \\
\hline Guinea pig & $\begin{array}{l}\text { DSM cut into pieces in PSS (in mM: } 137 \mathrm{NaCl}, 5.4 \mathrm{KCl}, 2 \mathrm{MgCl}_{2} \text {, } \\
2 \mathrm{CaCl}_{2}, 0.42 \mathrm{KH}_{2} \mathrm{P} 04,4.17 \mathrm{NaHCO}_{3}, 10 \mathrm{glucose}, 10 \mathrm{HEPES}, \mathrm{pH} \\
7.4 \text { with } \mathrm{NaOH} \text { ). DSM pieces placed for } 10 \mathrm{~min} \text { in in the following } \\
\text { digestion solution (in mM: } 80 \mathrm{Na} \text {-glutamate, } 55 \mathrm{NaCl}, 6 \mathrm{KCl}, 10 \mathrm{HEPES} \text {, } \\
11 \text { glucose, } 2 \mathrm{MgCl}_{2} \text {, and } 0.2 \mathrm{CaCl}_{2} \text { ) and then transferred to a vial } \\
\text { containing the same solution but with } 1 \mathrm{mg} / \mathrm{ml} \text { collagenase } 2,1 \mathrm{mg} / \mathrm{ml} \\
\text { trypsin inhibitor (sometimes omitted), } 1 \mathrm{mg} / \mathrm{ml} \text { fat-free bovine albumin, } \\
\text { for } \sim 70 \mathrm{~min} \text { at } 35^{\circ} \mathrm{C} \text { or } \sim 60 \mathrm{~min} \text { at } 37^{\circ} \mathrm{C} \text {. Single DSM cells were } \\
\text { obtained by trituration through a Pasteur pipette in the same solution } \\
\text { without calcium and enzymes. After trituration, Ca }{ }^{2+}(1 \mathrm{mM} \text { ) was added } \\
\text { and the cells were stored at } 4^{\circ} \mathrm{C} \text {. The cells were always used on the } \\
\text { same day. }\end{array}$ & $\begin{array}{l}\text { Bonev \& Nelson }(1993)^{53,54} \\
\text { Heppner et al. }(1997)^{26} \text { Petkov } \\
\text { et al. }(2001)^{47} \text { Shieh et al. }(2001 \text {, } \\
2007)^{48,49}\end{array}$ \\
\hline Guinea pig, mouse, rat, and human & $\begin{array}{l}\text { Protocol utilizes a two-step enzymatic dissociation treatment following } \\
\text { sharp dissection in } \mathrm{Ca}^{2+} \text {-free digestion solution (in mM: } 80 \mathrm{Na}- \\
\text { glutamate, } 55 \mathrm{NaCl}, 6 \mathrm{KCl}, 10 \mathrm{HEPES}, 11 \mathrm{glucose} \text {, and } 2 \mathrm{MgCl}_{2} \text { ). } \\
\text { First, DSM pieces were treated for } 25-45 \mathrm{~min} \text { at } 37^{\circ} \mathrm{C} \text { with } 1-2 \mathrm{mg} / \mathrm{ml} \\
\text { papain, } 1 \mathrm{mg} / \mathrm{ml} \text { dithioerythreitol and } 1 \mathrm{mg} / \mathrm{ml} \text { bovine serum albumin } \\
\text { in dissociation solution (in mM: } 80 \text { monosodium glutamate, } 55 \mathrm{NaCl} \text {, } \\
6 \mathrm{KCl}, 2 \mathrm{MgCl}, 10 \mathrm{HEPES} \text {, and } 10 \text { glucose, adjusted to } \mathrm{pH} 7.3 \text { with } \\
\mathrm{NaOH} \text { ) and then DSM pieces transferred to digestion solution containing } \\
1-5 \mathrm{mg} / \mathrm{ml} \text { collagenase } \mathrm{XI}\left(\text { Sigma) or collagenase type } 2,1 \mathrm{mg} / \mathrm{ml}^{2}\right. \\
\text { bovine serum albumin, } 0 \text { or } 1 \mathrm{mg} / \mathrm{ml} \text { trypsin inhibitor and } 100 \mu \mathrm{M} \mathrm{Ca}{ }^{2+} \text {, } \\
\text { for } 6-30 \text { min. Following incubation, the digested tissue was washed } \\
\text { several times in digestion solution without enzymes and } \mathrm{Ca}^{2+} \text { and then } \\
\text { gently triturated to yield single smooth muscle cells. }\end{array}$ & 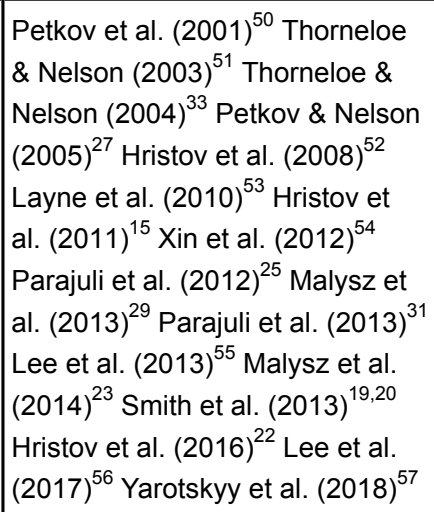 \\
\hline
\end{tabular}


Table 1: Summary of enzymatic approaches used for isolating single DSM cells from urinary bladders of various species.

\begin{tabular}{|c|c|}
\hline Solution Type & Composition (in mM) \\
\hline DS (Dissection/Digestion Solution) & $\begin{array}{l}80 \mathrm{Na} \text {-glutamate, } 55 \mathrm{NaCl}, 6 \mathrm{KCl}, 10 \mathrm{HEPES}, 2 \mathrm{MgCl}_{2} \text {, and } 11 \text { glucose, } \\
\mathrm{pH} \text { adjusted to } 7.4 \text { (with } 10 \mathrm{M} \mathrm{NaOH} \text { ) }\end{array}$ \\
\hline DS-P (Papain-containing DS) & $\begin{array}{l}\text { DS containing } 1-2 \mathrm{mg} / \mathrm{ml} \text { papain, } 1 \mathrm{mg} / \mathrm{ml} \text { dithiothreitol and } 1 \mathrm{mg} / \mathrm{ml} \\
\text { bovine serum albumin }\end{array}$ \\
\hline DS-C (Collagenase-containing DS) & $\begin{array}{l}\text { DS solution containing } 1-2 \mathrm{mg} / \mathrm{ml} \text { collagenase type } \mathrm{II}, 1 \mathrm{mg} / \mathrm{ml} \text { bovine } \\
\text { serum albumin, } 0 \text { or } 1 \mathrm{mg} / \mathrm{ml} \text { trypsin inhibitor and } 100-200 \mu \mathrm{M} \mathrm{Ca}^{2+}\end{array}$ \\
\hline P (Pipette) & $\begin{array}{l}110 \mathrm{CsOH}, 110 \text { aspartic acid, } 10 \mathrm{NaCl}, 1 \mathrm{MgCl}_{2}, 10 \mathrm{HEPES}, 0.05 \\
\mathrm{EGTA} \text {, and } 30 \mathrm{CsCl}, \mathrm{pH} \text { adjusted to } 7.2 \text { with } \mathrm{CsOH} \text {, and supplemented } \\
\text { with amphotericin-B }(300-500 \mu \mathrm{g} / \mathrm{ml})\end{array}$ \\
\hline E (Extracellular) & $\begin{array}{l}10 \text { tetraethylammonium chloride (TEA), } 6 \mathrm{CsCl}, 124 \mathrm{NaCl}, 1 \mathrm{MgCl}_{2}, 2 \\
\mathrm{CaCl}_{2}, 10 \mathrm{HEPES} \text {, and } 10 \text { glucose, } \mathrm{pH} \text { adjusted to } 7.3-7.4 \text { with } \mathrm{NaOH} \text { or } \\
\mathrm{CsOH} \text {, and } 0.002-3(2-3 \mathrm{mM}) \text { nifedipine }\end{array}$ \\
\hline
\end{tabular}

Table 2: Compositions of dissection/digestion solution (DS), and pipette and extracellular solutions used in perforated patch-clamp experiments.

\section{Discussion}

The procedures described here explain the steps involved in the preparation of viable, freshly isolated DSM cells from whole thickness human urinary bladder specimens using enzymatic digestion and in the recording of whole-cell cation currents sensitive to the TRPM4 channel inhibitor 9-phenanthrol employing the amphotericin-B perforated patch-clamp approach. The enzymatic procedure relies on a two-step sequential exposure referred to herein as the sequential papain-collagenase digestion method. DSM tissues are first treated with papain and dithiothreitol (an enzyme stabilizing agent) under a nominal $\mathrm{Ca}^{2+}$-free condition, followed in the second step by collagenase type II in the presence of low $\mathrm{Ca}^{2+}$. The rationale for carrying out papain digestion under low $\mathrm{Ca}^{2+}$ conditions in smooth muscle cells dates back to the late 1980's. Freshly isolated carotid artery smooth muscle cells prepared with papain displayed an elongated shape, showed viability (resistance to Trypan Blue uptake) and responded to contractile stimuli (higher $\mathrm{Ca}^{2+}$ and histamine $)^{65}$. Years later, this method was applied in the preparation of DSM cells (see Table 1). The choice of collagenase type II rather than other types relates to its relatively high proteolytic activity ideally suited for smooth muscle tissues including DSM. Indeed, collagenase treatment alone could yield single DSM cells albeit requiring extensive enzyme exposure $(\geq 60 \mathrm{~min})^{53,54}$. Since collagenase activity depends on $\mathrm{Ca}^{2+}$ and the enzyme is inactive under the $\mathrm{Ca}^{2+}$-free conditions, optimum enzymatic digestion of DSM pieces requires the presence of $\mathrm{Ca}^{2+66}$. In our case, DS-C contains 100-200 $\mu \mathrm{M}\left[\mathrm{Ca}^{2+}\right.$ ( Table 2). After enzymatic treatment, digested DSM pieces are washed gently a number of times with cold DS without enzymes or $\mathrm{Ca}^{2+}$ to remove any enzyme bound to tissues. The ice-cold DS helps to preserve DSM cell integrity and to limit enzymatic activity of any remaining papain or collagenase. In the last step, trituration of enzyme-treated DSM pieces with a fire polished Pasteur pipette releases single DSM cell. DSM cells are either immediately placed onto a recording chamber for patch-clamp studies or other types of experimentation or stored on ice in DS for use later on the same day (typically within $8 \mathrm{hrs}$ of preparation, but the cells remain viable for up to $24 \mathrm{~h}$ ).

We identified several important considerations for successfully obtaining single DSM cells. The first pertains to the human DSM specimen source quality. To optimally preserve tissue integrity, DSM samples obtained from open bladder surgeries are placed in ice-cold DS as soon as possible and maintained in a cold environment. Specifically, upon surgical extraction from the patient, the bladder specimen is immediately placed on a fully prepared side table in the operating room. Gross examination of the whole specimen (usually obtained during radical or simple cystectomy) and its opening follow. After visual inspection, a piece of whole thickness urinary ladder specimen is removed from a remote area of the specimen grossly uninvolved with tumor and immediately placed into a cup (either 50 or $100 \mathrm{~mL}$ ) containing cold $\left(\sim 4{ }^{\circ} \mathrm{C}\right)$ Dissection Solution (DS) (Table 2) and then tightly closed with a lid. Due to the planned nature of the harvesting of the tissue, the operating room personnel and auxiliary staff doing the harvesting are alerted at the start of the surgical case in order to have the materials available in the operating room at the time of tissue extraction. These precautions along with the routine, repetitive nature of the processing steps keep the warm ischemia time for the tissue - from extraction to placement in the chilled container with DS solution - to less than 5 min. The container is then placed in a refrigerator or on ice in a cooler to maintain the cold environment and transported (ice-cold) to the laboratory. Once the specimen arrives in the laboratory, dissection and enzymatic dissociation steps commence. It is very difficult to predict whether a given DSM specimen will yield high quality DSM cells following enzymatic dissociation, so we proceed with the enzymatic dissociation steps. In many cases, in parallel with electrophysiological experiments, our group conducts isometric tension recordings on DSM strips prepared from the same DSM specimens. We have found that we can usually obtain high quality DSM cells from preparations that also successfully provide viable strips for isometric contraction studies (our unpublished observation).

The second factor relates to different enzyme lot variabilities. We observed that for both papain and collagenase type II, each time a new lot of enzyme arrives from a supplier, the enzyme activity in DS for tissue digestion can vary. We, hence, routinely optimize the enzyme concentration and incubation intervals for each new lot. To minimize the lot variability contribution, we order larger quantities of the same lot and make a large batch of stock solutions in $2 \mathrm{~mL}$ aliquots of enzymes and store them at $\sim-20^{\circ} \mathrm{C}$ until use. Over time, however, frozen stocks (stored up to 2 weeks) can lose their enzymatic activity. The third variable relates to the temperature of enzyme digestion treatments. Enzymatic activities of both papain and collagenase display temperature-dependency. Papain and collagenase type II exhibit activity in the temperature ranges encompassing normal body physiology ${ }^{67,68}$. Therefore, we aim to maintain the enzyme treatments stable at $\sim 37^{\circ} \mathrm{C}$ avoiding higher temperatures to preserve DSM cell integrity. The fourth consideration concerns the variability of the quality of DSM cells present within each preparation ranging from highly viable (exhibiting excellent classical smooth muscle characteristics) to non-healthy, over-digested cells. A prolonged enzyme incubation interval is one of the main reasons for obtaining a high number of damaged cells. Excessive enzyme treatments 
also impair protein structures of ion channels, receptors, and transporters, adversely affecting their functionality. Interpretation of results obtained from enzymatically obtained, freshly isolated cells should bear this consideration in mind. Optimization of enzyme digestion conditions aims to increase the percentage of highly viable cells. Experimental approaches relying on a higher number of viable cells such as microarray analyses require more robust optimizations than those successfully carried out on fewer cells such as single-cell patch-clamp electrophysiology or $\mathrm{Ca}^{2+}$ imaging. Consideration of the aforementioned factors has guided our research efforts over the last decade in obtaining high quality single DSM cells.

The perforated patch-clamp technique has been a mainstay electrophysiological approach for over a quarter of a century. Several publications provide details of the technical considerations ${ }^{69,70,71,72,73}$. Cell perforation can be obtained with amphotericin-B, nystatin, gramicidin, or $\beta-$ escin (see reference ${ }^{32}$ for overview of each). The main advantage of perforated patch-clamp recordings over other electrophysiological approaches is that the native intracellular environment - including intracellular $\mathrm{Ca}^{2+}$ and signaling molecules (e.g., cAMP, PKA, phosphates, and phosphodiesterases) - is preserved. This technique is, hence, ideally suited for investigating whole-cell ion channel currents and their regulatory mechanisms under near physiological conditions. A key caveat is that intracellular cell composition cannot be precisely controlled unlike other electrophysiological methods such as conventional whole-cell and single-channel excised-patch (inside- and outside-out) recordings. In our experience, three factors routinely contribute to successful experimental outcomes of amphotericin-B-perforated patch-clamp experiments. The first is the quality of the DSM cell chosen to attempt a recording. When DSM cells are highly viable displaying a semi-contractile (serpentine-like), high-contrast shiny appearance with a well-defined halo around the cell surface and attach tightly to the glass bottom of the recording chamber then giga-seal formation and cell perforation occur relatively easy. The second and third factors for success, respectively, relate to quality of source and solubilization of amphotericin-B (in dimethyl sulfoxide/DMSO and intracellular pipette solution). We observed discrepancies among different suppliers in terms of source and lot variabilities. Each day we prepare a fresh solution of amphotericin-B stock solution from powder followed by its dilution in intracellular pipette solution. These steps require extensive sonication and vortexing. With freshly made amphotericinB-containing pipette solution, successful cell perforation $(<50 \mathrm{M} \Omega)$ following giga-seal formation can be usually obtained within 30 min. The concentration of amphotericin-B in the pipette solution also requires optimization dependent on the amphotericin-B lot and source. Under our experimental conditions, the final amphotericin-B concentrations in the pipette range from 200 to $500 \mu \mathrm{g} / \mathrm{mL}$. Since amphotericin-B exhibits light sensitivity, its solutions need to be kept in the dark. Using the amphotericin-B perforated patch-clamp technique, our group recorded voltagestep induced $\mathrm{K}^{+}, \mathrm{Ca}^{2+}$, and non-selective cation currents from human, guinea pig, mouse, and/or rat DSM cells ${ }^{17,21,22,23,29,30,31,35,60}$. Here, we describe conditions for recording non-selective cation currents in human DSM cells. 9-Phenanthrol, a blocker of TRPM4 channels, attenuated voltage-step induced currents supporting the role of these channels in the control of DSM excitability. As a note, it usually requires at least 45 min after obtaining a giga-seal and initiation of perforation to record optimum stable voltage-step induced non-selective cation currents. Voltage ramps can also be used as an alternative to voltage-step protocols ${ }^{30,64}$. Here, a voltage-step protocol from a hyperpolarized holding membrane potential was preferred rather than a ramp protocol since the former approach minimizes the effect of voltage-dependent inactivation and allows for averaging of evoked current over a duration of a voltage-step where the ramp provides a single data point per voltage. The latter point especially applies to human DSM cells as the currents show variable activity during voltage steps (Figure $\mathbf{5}$ and Figure 6). The amphotericin$B$ perforated patch-clamp technique has been essential in identifying the properties of DSM cells and other cell types and will continue to aide in providing novel discoveries in the future. Furthermore, freshly isolated single DSM cells can be successfully used for measuring whole-cell $\mathrm{K}^{+}, \mathrm{Cl}^{-}$, and $\mathrm{Ca}^{2+}$ currents with the conventional mode of the patch-clamp technique, membrane potential recording with the current clamp, and single channel recordings as exemplified by our prior reports ${ }^{23,29,35,64}$.

In addition to single cell patch-clamp methods, freshly isolated DSM cells can be studied with other technical approaches including $\mathrm{Ca}^{2+}$ imaging, RT-PCR/q-RT-PCR, immunocytochemistry, in situ proximity ligation assay, and genomic approaches (e.g., microarray, RNA-seq, CHIPseq) ${ }^{15,18,30,33,34}$. As single cell transcriptome determination methods continue to evolve and become highly sensitive, we envision in a future ability to routinely and specifically link electrical or pharmacological properties of individual DSM cells with their transcriptome/proteome profiles. This will be achieved by first recording from a DSM cell and then extracting mRNA or protein followed by transcriptomic/proteomic analyses. Although such methods have been tested already in non-DSM cells, they are at present technically challenging, lack sensitivity to be considered routine, and limited to successful detection of a few selected gene products ${ }^{74}$. Function-molecular profile expression linking studies when done on DSM cells obtained from urinary bladders derived from control and diseased patient-donors will provide insights into physiological processes essential for driving normal DSM functions, pathogenesis, and in identifying effective novel therapeutic approaches.

\section{Disclosures}

None.

\section{Acknowledgments}

This work was supported by NIH-R01DK106964 and P20DK123971 grants to Georgi V. Petkov. The authors thank Dr. Viktor Yarotskyy and Ms. Sarah Maxwell for critical evaluation of the manuscript. We are also grateful to urology staff surgeons at MUSC and UTHSC: Drs. Thomas Keane, Harry Clarke, Stephen Savage, Ross Rames, Sandip Prasad, Jonathan Picard, Christopher Ledbetter, and Anthony Patterson as well as the MUSC and UTHSC Urology residents: Drs. Taylor Vaughan, Samuel Walker Nickles, Matthew Young, Erin Burns, Justin Ellett, Ryan Levey, Austin Younger, Mark Currin, Nima Baradaran, Olugbemisola McCoy, Tracy Tipton, Bryce Wyatt, Alyssa Greiman, Sarah Starosta, Aaron Bloch, Christine Callaway, Lucille Cox, Christian Dewan, Erin Heitman, Bradley Houston, Stephen Legg, Robert S. Libby, Cole Locklear, Kristen Marley, Monica O'Hanlon, Patrick Probst, Cynthia Sharadin, Elizabeth Tourville, Daniel Zapata for their help with human tissue collection.

\section{References}

1. Andersson, K. E., Arner, A. Urinary bladder contraction and relaxation: physiology and pathophysiology. Physiological Reviews. 84 (3), 935-986 (2004). 
2. Brading, A. F., Brain, K. L. Ion channel modulators and urinary tract function. In Urinary Tract (Editors: Andersson, K.E., Michel, M.C.), Springer-Verlag Berlin Heidelberg, Germany; Part of Handbook of Experimental Pharmacology book series. 202, 375-393 (2011).

3. Brading, A. F. Spontaneous activity of lower urinary tract smooth muscles: correlation between ion channels and tissue function. Journal of Physiology. $\mathbf{5 7 0}$ (Pt 1), 13-22 (2006).

4. Brading, A. F., Heaton, J. P., Hashitani, H. A survey of commonalities relevant to function and dysfunction in pelvic and sexual organs. International Journal of Impotence Research. 20 (1), 1-16 (2008).

5. Petkov, G. V. Role of potassium ion channels in detrusor smooth muscle function and dysfunction. Nature Reviews Urology. 9 (1), $30-40$ (2012).

6. Andersson, K. E. Treatment-resistant detrusor overactivity--underlying pharmacology and potential mechanisms. International Journal of Clinical Practice Supplement. 151, 8-16 (2006).

7. Sui, G. P., Wu, C., Fry, C. H. The electrophysiological properties of cultured and freshly isolated detrusor smooth muscle cells. Journal of Urology. 165 (2), 627-632 (2001).

8. Kropp, B. P. et al. Characterization of cultured bladder smooth muscle cells: assessment of in vitro contractility. Journal of Urology. 162 (5), 1779-1784 (1999).

9. Bonev, A., Isenberg, G. Arginine-vasopressin induces mode-2 gating in L-type $\mathrm{Ca}^{2+}$ channels (smooth muscle cells of the urinary bladder of the guinea-pig). Pflügers Archive - European Journal of Physiology. 420 (2), 219-222 (1992).

10. Schneider, P., Hopp, H. H., Isenberg, G. Ca ${ }^{2+}$ influx through ATP-gated channels increments $\left[\mathrm{Ca}^{2+}\right]_{i}$ and inactivates $\mathrm{I}_{\mathrm{Ca}}$ in myocytes from guinea-pig urinary bladder. Journal of Physiology. 440 479-496 (1991).

11. Wellner, M. C., Isenberg, G. Properties of stretch-activated channels in myocytes from the guinea-pig urinary bladder. Journal of Physiology. 466 213-227 (1993).

12. Wellner, M. C., Isenberg, G. Stretch-activated nonselective cation channels in urinary bladder myocytes: importance for pacemaker potentials and myogenic response. Experientia Supplementum. 66 93-99 (1993).

13. Klockner, U., Isenberg, G. Action potentials and net membrane currents of isolated smooth muscle cells (urinary bladder of the guinea-pig). Pflügers Archive - European Journal of Physiology. 405 (4), 329-339 (1985).

14. Moore, E. D. et al. Organization of $\mathrm{Ca}^{2+}$ release units in excitable smooth muscle of the guinea-pig urinary bladder. Biophysical Journal. 87 (3), 1836-1847 (2004).

15. Hristov, K. L., Chen, M., Kellett, W. F., Rovner, E. S., Petkov, G. V. Large conductance voltage- and Ca ${ }^{2+}$-activated $\mathrm{K}^{+}$channels regulate human detrusor smooth muscle function. American Journal of Physiology - Cell Physiology. 301 (4), C903-912 (2011).

16. Afeli, S. A., Rovner, E. S., Petkov, G. V. SK but not IK channels regulate human detrusor smooth muscle spontaneous and nerve-evoked contractions. American Journal of Physiology - Renal Physiology. 303 (4), F559-568 (2012).

17. Hristov, K. L. et al. $\mathrm{K}_{\mathrm{v}} 2.1$ and electrically silent $\mathrm{K}_{\mathrm{v}}$ channel subunits control excitability and contractility of guinea pig detrusor smooth muscle. American Journal of Physiology - Cell Physiology. 302 (2), C360-C37 (2012).

18. Afeli, S. A., Malysz, J., Petkov, G. V. Molecular expression and pharmacological evidence for a functional role of $\mathrm{K}_{\mathrm{v}} 7$ channel subtypes in Guinea pig urinary bladder smooth muscle. PLoS One. 8 (9), e75875 (2013)

19. Smith, A. C. et al. TRPM4 channel: a new player in urinary bladder smooth muscle function in rats. American Journal of Physiology - Renal Physiology. 304 (7), F918-929 (2013).

20. Smith, A. C. et al. Novel role for the transient potential receptor melastatin 4 channel in guinea pig detrusor smooth muscle physiology. American Journal of Physiology - Cell Physiology. 304 (5), C467-47 (2013).

21. Hristov, K. L., Smith, A. C., Parajuli, S. P., Malysz, J., Petkov, G. V. Large-conductance voltage- and $\mathrm{Ca}^{2+}$-activated $\mathrm{K}^{+}$channel regulation by protein kinase C in guinea pig urinary bladder smooth muscle. American Journal of Physiology - Cell Physiology. 306 (5), C460-470 (2014).

22. Hristov, K. L. et al. Novel regulatory mechanism in human urinary bladder: central role of transient receptor potential melastatin 4 channels in detrusor smooth muscle function. American Journal of Physiology - Cell Physiology. 310 (7), C600-611 (2016).

23. Malysz, J., Afeli, S. A., Provence, A., Petkov, G. V. Ethanol-mediated relaxation of guinea pig urinary bladder smooth muscle: involvement of BK and L-type $\mathrm{Ca}^{2+}$ channels. American Journal of Physiology - Cell Physiology. 306 (1), C45-58 (2014).

24. Montgomery, B. S., Fry, C. H. The action potential and net membrane currents in isolated human detrusor smooth muscle cells. Journal of Urology. 147 (1), 176-184 (1992).

25. Parajuli, S. P., Soder, R. P., Hristov, K. L., Petkov, G. V. Pharmacological activation of small conductance calcium-activated potassium channels with naphtho[1,2-d]thiazol-2-ylamine decreases guinea pig detrusor smooth muscle excitability and contractility. Journal of Pharmacology and Experimental Therapeutics. 340 (1), 114-123 (2012).

26. Heppner, T. J., Bonev, A. D., Nelson, M. T. $\mathrm{Ca}^{2+}$-activated $\mathrm{K}^{+}$channels regulate action potential repolarization in urinary bladder smooth muscle. American Journal of Physiology - Cell Physiology. 273 (1 Pt 1), C110-C117 (1997).

27. Petkov, G. V., Nelson, M. T. Differential regulation of $\mathrm{Ca}^{2+}$-activated $\mathrm{K}^{+}$channels by beta-adrenoceptors in guinea pig urinary bladder smooth muscle. American Journal of Physiology - Cell Physiology. 288 (6), C1255-C1263 (2005).

28. Herrera, G. M., Etherton, B., Nausch, B., Nelson, M. T. Negative feedback regulation of nerve-mediated contractions by $\mathrm{K}_{\mathrm{Ca}}$ channels in mouse urinary bladder smooth muscle. American Journal of Physiology - Regulatory Integrative Comparative Physiology. 289 (2), R402-R409 (2005).

29. Malysz, J., Rovner, E. S., Petkov, G. V. Single-channel biophysical and pharmacological characterizations of native human large-conductance calcium-activated potassium channels in freshly isolated detrusor smooth muscle cells. Pflügers Archive - European Journal of Physiology. 465 (7), 965-975 (2013).

30. Provence, A., Angoli, D., Petkov, G. V. $\mathrm{K}_{\mathrm{v}} 7$ channel pharmacological activation by the novel activator ML213: role for heteromeric $\mathrm{K}_{\mathrm{v}} 7.4 / \mathrm{Kv} 7.5$ channels in guinea pig detrusor smooth muscle function. Journal of Pharmacology and Experimental Therapeutics. 364 (1), 131-144 (2018).

31. Parajuli, S. P. et al. Control of urinary bladder smooth muscle excitability by the TRPM4 channel modulator 9-phenanthrol. Channels (Austin). 7 (6), 537-540 (2013).

32. Ishibashi, H., Moorhouse, A. J., Nabekura, J. Perforated whole-cell patch-clamp technique: a user's guide. In Patch Clamp Techniques: From Beginning to Advanced Protocols (Editor: Okada, Y.), Springer, Tokyo, Japan. 4. 71-83 (2012).

33. Provence, A., Rovner, E. S., Petkov, G. V. Regulation of transient receptor potential melastatin 4 channel by sarcoplasmic reticulum inositol trisphosphate receptors: Role in human detrusor smooth muscle function. Channels (Austin). 11 (5), 459-466 (2017).

34. Hristov, K. L. et al. Suppression of human detrusor smooth muscle excitability and contractility via pharmacological activation of large conductance $\mathrm{Ca}^{2+}$-activated K ${ }^{+}$channels. American Journal of Physiology - Cell Physiology. 302 (11), C1632-1641 (2012). 
35. Xin, W., Soder, R. P., Cheng, Q., Petkov, G. V. Inhibition of phosphodiesterases relaxes detrusor smooth muscle via activation of the large conductance voltage- and $\mathrm{Ca}^{2+}$-activated $\mathrm{K}^{+}$channel. American Journal of Physiology - Cell Physiology. 302 (9), C1361-1370 (2012).

36. Hristov, K. L. et al. Neurogenic detrusor overactivity is associated with decreased expression and function of the large conductance voltageand $\mathrm{Ca}^{2+}$-activated $\mathrm{K}^{+}$channels. PLoS One. 8 (7), e68052 (2013).

37. Hristov, K. L., Parajuli, S. P., Provence, A., Rovner, E. S., Petkov, G. V. Nongenomic modulation of the large conductance voltage- and Ca ${ }^{2+}-$ activated $\mathrm{K}^{+}$channels by estrogen: A novel regulatory mechanism in human detrusor smooth muscle. Physiological Reports. 5 (14) (2017).

38. Parajuli, S. P. et al. Functional link between muscarinic receptors and large-conductance $\mathrm{Ca}^{2+}$-activated $\mathrm{K}^{+}$channels in freshly isolated human detrusor smooth muscle cells. Pflügers Archiv - European Journal of Physiology. 467 (4), 665-675 (2015).

39. Malysz, J., Rovner, E. S., Petkov, G. V. Single-channel biophysical and pharmacological characterizations of native human large-conductance calcium-activated potassium channels in freshly isolated detrusor smooth muscle cells. Pflügers Archiv - European Journal of Physiology. 465 (7), 965-975 (2013).

40. Thorneloe, K. S., Nelson, M. T. Properties of a tonically active, sodium-permeable current in mouse urinary bladder smooth muscle. American Journal of Physiology - Cell Physiology. 286 (6), C1246-1257 (2004).

41. Barry, M. J. et al. The American Urological Association symptom index for benign prostatic hyperplasia. The Measurement Committee of the American Urological Association. Journal of Urology. 148 (5), 1549-1557; discussion 1564 (1992).

42. Klockner, U., Isenberg, G. Calcium currents of cesium loaded isolated smooth muscle cells (urinary bladder of the guinea pig). Pflügers Archiv - European Journal of Physiology. 405 (4), 340-348 (1985).

43. Klockner, U., Isenberg, G. Tiapamil reduces the calcium inward current of isolated smooth muscle cells. Dependence on holding potential and pulse frequency. European Journal of Pharmacology. 127 (3), 165-171 (1986).

44. Weidelt, T., Isenberg, G. Augmentation of SR $\mathrm{Ca}^{2+}$ release by rapamycin and $\mathrm{FK} 506$ causes $\mathrm{K}^{+}$-channel activation and membrane hyperpolarization in bladder smooth muscle. British Journal of Pharmacology. 129 (7), 1293-1300 (2000).

45. Inoue, R., Brading, A. F. The properties of the ATP-induced depolarization and current in single cells isolated from the guinea-pig urinary bladder. British Journal of Pharmacology. 100 (3), 619-625 (1990).

46. Inoue, R., Brading, A. F. Human, pig and guinea-pig bladder smooth muscle cells generate similar inward currents in response to purinoceptor activation. British Journal of Pharmacology. 103 (4), 1840-1841 (1991).

47. Nakayama, S., Brading, A. F. Possible contribution of long open state to noninactivating $\mathrm{Ca}^{2+}$ current in detrusor cells. American Journal of Physiology - Cell Physiology. 269 (1 Pt 1), C48-54 (1995).

48. Nakayama, S., Brading, A. F. Interaction of $\mathrm{Ca}^{2+}$ agonist and depolarization on $\mathrm{Ca}^{2+}$ channel current in guinea pig detrusor cells. Journal of General Physiology. 106 (6), 1211-1224 (1995).

49. Gallegos, C. R., Fry, C. H. Alterations to the electrophysiology of isolated human detrusor smooth muscle cells in bladder disease. Journal of Urology. 151 (3), 754-758 (1994).

50. JournalFry, C. H., Gallegos, C. R., Montgomery, B. S. The actions of extracellular $\mathrm{H}^{+}$on the electrophysiological properties of isolated human detrusor smooth muscle cells. Journal of Physiology. 480 (Pt 1), 71-80 (1994).

51. Sui, G. P., Wu, C., Fry, C. H. A description of $\mathrm{Ca}^{2+}$ channels in human detrusor smooth muscle. BJU International Journal. 92 (4), $476-48$ (2003).

52. Wu, C., Sui, G., Fry, C. H. The role of the L-type $\mathrm{Ca}^{2+}$ channel in refilling functional intracellular $\mathrm{Ca}^{2+}$ stores in guinea-pig detrusor smooth muscle. Journal of Physiology. 538 (Pt 2), 357-369 (2002).

53. Bonev, A. D., Nelson, M. T. Muscarinic inhibition of ATP-sensitive $\mathrm{K}^{+}$channels by protein kinase $\mathrm{C}$ in urinary bladder smooth muscle. American Journal of Physiology - Cell Physiology. 265 (6 Pt 1), C1723-1728 (1993).

54. Bonev, A. D., Nelson, M. T. ATP-sensitive potassium channels in smooth muscle cells from guinea pig urinary bladder. American Journal of Physiology - Cell Physiology. 264 (5 Pt 1), C1190-1200 (1993).

55. Petkov, G. V., Heppner, T. J., Bonev, A. D., Herrera, G. M., Nelson, M. T. Low levels of $\mathrm{K}_{\text {ATP }}$ channel activation decrease excitability and contractility of urinary bladder. American Journal of Physiology - Regulatory Integrative Comparative Physiology. 280 (5), R1427-1433 (2001).

56. Shieh, C. C. et al. Functional implication of spare ATP-sensitive $\mathrm{K}^{+}$channels in bladder smooth muscle cells. Journal of Pharmacology and Experimental Therapeutics. 296 (3), 669-675 (2001).

57. Shieh, C. C. et al. Characterization of a novel ATP-sensitive $\mathrm{K}^{+}$channel opener, A-251179, on urinary bladder relaxation and cystometric parameters. British Journal of Pharmacology. 151 (4), 467-475 (2007).

58. Petkov, G. V. et al. Beta1-subunit of the $\mathrm{Ca}^{2+}$-activated $\mathrm{K}^{+}$channel regulates contractile activity of mouse urinary bladder smooth muscle. Journal of Physiology. 537 (Pt 2), 443-452 (2001).

59. Thorneloe, K. S., Nelson, M. T. Properties and molecular basis of the mouse urinary bladder voltage-gated K ${ }^{+}$current. Journal of Physiology. 549 (Pt 1), 65-74 (2003).

60. Hristov, K. L. et al. Stimulation of beta3-adrenoceptors relaxes rat urinary bladder smooth muscle via activation of the large-conductance $\mathrm{Ca}^{2+}$-activated K ${ }^{+}$channels. American Journal of Physiology - Cell Physiology. 295 (5), C1344-C1353 (2008).

61. Layne, J. J., Nausch, B., Olesen, S. P., Nelson, M. T. BK channel activation by NS11021 decreases excitability and contractility of urinary bladder smooth muscle. American Journal of Physiology - Regulatory Integrative Comparative Physiology. 298 (2), R378-R384 (2010).

62. Lee, H., Koh, B. H., Peri, L. E., Sanders, K. M., Koh, S. D. Functional expression of SK channels in murine detrusor PDGFRalpha ${ }^{+}$cells. Journal of Physiology. 591 (2), 503-513 (2013).

63. Lee, H. et al. Premature contractions of the bladder are suppressed by interactions between TRPV4 and SK3 channels in murine detrusor PDGFRalpha ${ }^{+}$cells. Scientific Reports. 7 (1), 12245 (2017).

64. Yarotskyy, V., Malysz, J., Petkov, G. V. Properties of single channel and whole-cell $\mathrm{Cl}^{-}$currents in guinea pig detrusor smooth muscle cells. American Journal of Physiology - Cell Physiology. 316 (5), C698-C710 (2019).

65. Driska, S. P., Porter, R. Isolation of smooth muscle cells from swine carotid artery by digestion with papain. American Journal of Physiology Cell Physiology. 251 (3 Pt 1), C474-481 (1986).

66. Seltzer, J. L., Welgus, H. G., Jeffrey, J. J., Eisen, A. Z. The function of $\mathrm{Ca}^{2+}$ in the action of mammalian collagenases. Archives of Biochemistry and Biophysics. 173 (1), 355-361 (1976).

67. Skelton, G. S. Papaya proteinases. I. Temperature-and pH-stability curves. Enzymologia. 35 (5), 270-274 (1968).

68. Petrova, D., Derekova, A., Vlahov, S. Purification and properties of individual collagenases from Streptomyces sp. strain 3B. Folia Microbiologica (Praha). 51 (2), 93-98 (2006).

69. Sharpe, E. J., St Clair, J. R., Proenza, C. Methods for the isolation, culture, and functional characterization of sinoatrial node myocytes from adult mice. Journal of Visualized Experiments. (116) (2016). 
70. Brueggemann, L. I., Mani, B. K., Haick, J., Byron, K. L. Exploring arterial smooth muscle $\mathrm{K}_{\mathrm{v}} 7$ potassium channel function using patch clamp electrophysiology and pressure myography. Journal of Visualized Experiments. (67), e4263 (2012).

71. Jarriault, D., Grosmaitre, X. Perforated patch-clamp recording of mouse olfactory sensory neurons in intact neuroepithelium: functional analysis of neurons expressing an identified odorant receptor. Journal of Visualized Experiments. (101), e52652 (2015).

72. Rae, J., Cooper, K., Gates, P., Watsky, M. Low access resistance perforated patch recordings using amphotericin B. Journal of Neuroscience Methods. 37 (1), 15-26 (1991).

73. Knutson, K. et al. Whole cell electrophysiology of primary cultured murine enterochromaffin cells. Journal of Visualized Experiments. (139) (2018).

74. Devienne, G., Le Gac, B., Piquet, J., Cauli, B. Single cell multiplex reverse transcription polymerase chain reaction after patch-clamp. Journal of Visualized Experiments. (136) (2018) 